\title{
De Dendê e Baianidade: restaurantes de comida baiana em Salvador
}

\author{
Taís de Sant'Anna Machado \\ Orientador: Edson Silva de Farias \\ Dissertação de Mestrado \\ Data da defesa: 13.11.2012
}

A pesquisa que fundamenta este trabalho tem como problemática fundamental compreender a relação entre caracteres extraordinários e ordinários que se estabelecem através da comida baiana. Para tanto, primeiramente, investiga a narrativa contida na construção estética e discursiva utilizada por registros de mídias artísticas, como literatura e música, no ínterim dos séculos XX e XXI, e de material turístico, bem como o enfoque, para abarcar a definição da comida baiana, de livros de culinária sobre o tema. Assim, destacando o repertório de ingredientes, pratos, modos de comer e de preparar que se definirão como extraordinariamente baianos, significando também o contexto mais amplo da identidade. Para pensar a relação que a rotina alimentar estabelece com esse ideário, o trabalho investiga, brevemente, a narrativa de comensais moradores da cidade, analisando de que modo significam os hábitos alimentares cotidianos e as possíveis apropriações em torno da comida étnica. $E$, para entender de que modo essa interação se dá no âmbito da produção da comida baiana, investiga a mercadoria proposta por restaurantes, enquanto instituições sociais fundamentais na definição de caracteres em torno do repertório idealizado da comida baiana, ao passo que também tem de preservar algumas características para não perderem o atestado étnico. A investigação demonstra de que modo a relação entre ordinário e extraordinário não se define em simples disjunção, mas em diversas formas de mediação que refletem sua coexistência e significação mútua. O que se observa é que a comida baiana idealizada permanece no cotidiano de moradores e estabelecimentos comerciais, em apropriações que lhe são próprias e que respondem a demandas dos hábitos alimentares e contemporâneos de produção. A afirmação da comida baiana enquanto bem cultural, em uma economia de serviços que marca a Bahia, é, assim, capaz de engendrar novos rituais de consumo e produção para atender às demandas da contemporaneidade e garantir a permanência do consumo evidentemente, ainda que não de forma consciente.

Palavras-chave: Comida Baiana, Restaurante Étnico, Bem Cultural, Identidade, Turismo. 